\title{
EXPERIMENTALWORKS
}

UDC 577.151.042: 577.152.34

doi: https://doi.org/10.15407/ubj89.05.015

\section{INFLUENCE OF CATIONS ON FURIN ACTIVITY}

\author{
T. V. OSADCHUK ${ }^{1}$, O. V. SHYBYRYN ${ }^{1}$, A. V. SEMYROZ \\ O. M. BONDARENKO', V. K. KIBIREV $V^{1,2}$ \\ ${ }^{1}$ Institute of Bioorganic Chemistry and Petrochemistry, \\ National Academy of Sciences of Ukraine, Kyiv; \\ e-mail: osadchuk@bpci.kiev.ua; \\ ${ }^{2}$ Palladin Institute of Biochemistry, National Academy of Sciences of Ukraine, Kyiv
}

Furin is the most studied proprotein convertase which processes inactive protein precursors, converting them into biologically active polypeptides. We have investigated cation effects of cesium, strontium, cadmium, iron, cobalt and nickel on the furin activity. It was shown that in the presence of $\mathrm{Ca}^{2+}(1 \mathrm{mM})$ these ions were able to activate the enzyme, and the peak position of its activity depends on the nature of the ion. Particularly, for $\mathrm{Fe}^{2+}$ it was observed at the ion concentration of $15 \mathrm{mM}$, whereas for $\mathrm{Cd}^{2+}, \mathrm{Co}^{2+}$ and $\mathrm{Ni}^{2+}$ the maximum activity of furin was at $20 \mathrm{mM}$, for $\mathrm{Cs}^{+}$the peak was at a concentration of $30 \mathrm{mM}$, and for strontium ions it was $40 \mathrm{mM}$. The affinity of the cations for furin was estimated by Lineweaver-Burk plots for low concentrations of ions for the ascending branch of furin activity dependence on the cation concentration. It was found that their affinity in comparison with $\mathrm{Ca}^{2+}$ was sharply reduced ( 18-150 times). The studied cations (under physiological conditions) were shown not to be able to compete with calcium ions for furin, and in natural environment they cannot influence its activity.

Key words: furin, cation effect, furin activity, activation, inhibition.

$\mathrm{F}$ urin (EC 3.4.21.75) - a Ca ${ }^{2+}$-dependent serine endoproteinase - belongs to the family of socalled proprotein convertases (PCs), which process the inactive protein precursors, transforming them into biologically active hormones, growth factors, receptors, matrix metalloproteinases, clotting factors, adhesion molecules, etc. [1-3]. In addition to the normal physiological functions, the enzyme participates in the development of such pathological conditions, as cancer and metastasis, neurodegenerative diseases, obesity and diabetes, atherosclerosis, as well as viral and bacterial infections [3, 4]. Therefore furin is considered as a promising target for the synthesis of appropriate inhibitors and for the creation on their basis the potential therapeutic agents of a new generation [5-7].

As furin recognizes a region of the polypeptide chain enriched with the residues of the basic amino acids: -Arg-X -(Lys/Arg)-Arg- $\downarrow$, where $n=0,2,4,6$, and $\mathrm{X}$ is any amino acid other than Cys in its natural substrates [4], thus positively charged substituents are introduced into the enzyme inhibitor structure: the guanidine group or its mimetics, such as amidine, amidinohydrazone, aminomethylbenzamidine and other groups [5, 8-11]. X-ray structural analysis of human furin [12] showed the importance of electrostatic interactions for the realization of binding inhibitors to enzyme, although hydrophobic contacts, as well as the formation of wide network of hydrogen bonds, are also very important for catalysis [12]. Furin fulfills its functions in the cell when recycles from the trans-Golgi network (TGN) to the surface membrane and back. In this case, it can be located in several compartments: in TGN, on the cells surface and in endosomes [3]. As the ionic environment, $\mathrm{pH}$ and the hydrophobicity within these organelles can

(C) 2017 Osadchuk T. V. et al. This is an open-access article distributed under the terms of the Creative Commons Attribution License, which permits unrestricted use, distribution, and reproduction in any medium, provided the original author and source are credited. 
be markedly different [13], it was necessary to study in model experiments the effect of various components of the reaction medium on the enzyme activity.

There are some data about the effect of certain ions on furin activity in literature. In particular, it is shown that it is $\mathrm{Ca}^{2+}$-dependent enzyme $\left(K_{0.5}=200 \mu \mathrm{M}\right)$ and maximum of its activity is observed at a calcium ion concentration of 1-2 $\mathrm{mM}$ [1].

According to the X-ray structure analysis there are three $\mathrm{Ca}^{2+}$ binding sites in the structure of the human enzyme; two of them are located at the surface of the molecule, and last one that stabilizes furin conformation is next to the active site [12]. Sodium ions, for which a special binding site is also found in the protein globule [12], at concentration $0-100 \mathrm{mM}$ weakly affect the catalytic properties of furin [14]. The dependence of the enzyme activity on concentration of $\mathrm{K}^{+}$-ions is described by a bell-shaped curve $[14,15]$. Furin is also able to bind magnesium ions $\left(K_{d} \sim 1.1 \mathrm{mM}\right)$ [16], but their effect depends on the structure of the substrate used [16]. Thus, the using of synthetic FRET-decapeptides, which are derivatives of viral proteins, usually stimulates the activity of furin with magnesium ions. In contrast, for substrates, derivatives of human proteins, the inhibition of enzyme activity is observed under the action of $\mathrm{MgCl}_{2}$ [16]. The decrease in the activity of furin under the influence of magnesium ions takes place when using the synthetic fluorogenic substrate AcArg-Val-Arg-Arg-AMC [16].

In respect of other cations, it was found that $\mathrm{Zn}^{2+}$ or $\mathrm{Hg}^{2+}$ at the concentration of $1 \mathrm{mM}$ completely suppressed the activity of furin [1]. $\mathrm{Cu}^{2+}$ can also effectively block furin $\left(\mathrm{IC}_{50}=0.14 \mu \mathrm{M}\right)$ [17]. Zink, mercury and copper belong to the group of heavy metals (HM) that includes more than 40 elements of D. I. Mendeleyev's system. So, $\mathrm{Hg}, \mathrm{Pb}, \mathrm{Cd}$ and their compounds are highly toxic substances capable of contaminating the environment [18] and accumulating in live organisms. A number of $\mathrm{HM}(\mathrm{Fe}, \mathrm{Cu}, \mathrm{Zn}$, Mo, etc.) belong to trace elements which take part in realization of normal biological processes, but a certain threshold concentration being exceeded, they determine the development of pathologic states [19]. That is why, it is important to investigate their effect on the enzyme in the model experiments.

The aim of our work is to study the effect of such $\mathrm{HM}$ cations as $\mathrm{Cs}^{+}, \mathrm{Sr}^{2+}, \mathrm{Cd}^{2+}, \mathrm{Fe}^{2+}, \mathrm{Co}^{2+}$ and $\mathrm{Ni}^{2+}$ on the catalytic properties of furin and evaluation of possible negative effect of the cations on the enzyme activity.

\section{Materials and Methods}

Reagents and preparations. We used the following commercial salts: $\mathrm{CsCl}, \mathrm{SrCl}_{2} \cdot 6 \mathrm{H}_{2} \mathrm{O}$, $\mathrm{CdCl}_{2} \cdot 2,5 \mathrm{H}_{2} \mathrm{O}, \mathrm{NiSO}_{4} \cdot 7 \mathrm{H}_{2} \mathrm{O}, \mathrm{CoF}_{2} \cdot 4 \mathrm{H}_{2} \mathrm{O}, \mathrm{FeSO}_{4}$ (anhydrous) and also aqueous solutions of $\mathrm{CaCl}_{2}(1 \mathrm{M})$ and $\mathrm{MgCl}_{2}(10 \%)$ of both domestic company Ukrreakhim, and foreign ones Fluka (Switzerland) and Merck (Germany). Commercial products were also EDTA (Serva, Germany), HEPES (Sigma, USA), $\beta$-mercaptoethanol, Triton (Fluka, Switzerland).

The fluorogenic substrate Boc-Arg-Val-ArgArg-AMC (Bachem, Switzerland) and the truncated recombinant human furin $(2000 \mathrm{U} / \mathrm{ml})$ from New England BioLabs (USA) were used in the work. For the unit of furin activity, an amount of enzyme was taken that, under standard conditions, cleaves 1 pmol of 7-amino-4-methylcoumarin (AMC) from the fluorogenic substrate in $1 \mathrm{~min}$. Before experiments, the solution of the commercial enzyme preparation was diluted with a working HEPES buffer ( $\mathrm{pH}$ 7.3) 20-80 times and the resulting solution was used to perform the enzymatic reaction.

Determination of furin activity. An aliquot of the furin solution containing 1 unit of the enzyme activity was incubated in $\mathrm{pH} 7.3$ buffer $(100 \mathrm{mM}$ HEPES, $1 \mathrm{mM} \mathrm{CaCl}_{2}, 0.5 \%$ Triton X-100 and $1 \mathrm{mM}$ $\beta$-mercaptoethanol) for $1 \mathrm{~h}$ at $37^{\circ} \mathrm{C}$ with the fluorogenic substrate $(75-250 \mu \mathrm{M})$ in a sample of $150 \mu \mathrm{l}$. The reaction was stopped by the addition of $2 \mathrm{ml}$ EDTA (initial concentration $5 \mathrm{mM}$ ) and relative fluorescence was measured on a PTI Quanta Master 40 spectrofluorimeter (Canada) at an excitation wavelength of $380 \mathrm{~nm}$ and emission of $460 \mathrm{~nm}$. The width of both slots was $2 \mathrm{~nm}$. The fluorescence readings were recorded for $60 \mathrm{sec}$. The values of the Michaelis constants were determined by plotting the Lineweaver-Burk graphs in three independent experiments.

Determination of the effectiveness of the action of salts. The reaction was performed for $1 \mathrm{~h}$ as described above in the absence of calcium ions or in the presence of $1 \mathrm{mM} \mathrm{CaCl}_{2}$ and increasing concentrations $(0-80 \mathrm{mM})$ of salts specified above. The total volume of the sample was $150 \mu \mathrm{l}$. The reaction was terminated by adding EDTA and the fluorescence of the corresponding solution was measured as described above.

The plotting and processing of the measurement results was carried out by WordExel program using at least two independent experiments. 


\section{Results and Discussion}

The results of studying the effects of cesium, strontium, cadmium, iron, cobalt and nickel, on furin activity are presented below. In particular, it was studied how these ions affect the efficiency of the enzymatic reaction (Fig. 1, $A$ ) with the synthetic tetrapeptide Boc-Arg-Val-Arg-Arg-AMC, and also the concentration dependence of the ion effects on the enzyme (Fig. 1, B). According to our data with using the synthetic substrate Boc-RVRR-AMC magnesium ions at a concentration of $5 \mathrm{mM}$ activate furin, whereas in the article [16] Izidoro M. A. et al. observed a decrease of its activity, when working with Ac-RVRR-AMC.

The reaction was carried out in standard HEPES buffer (100 mM), $\mathrm{pH} 7.3$ both in the absence and in the presence of $1 \mathrm{mM} \mathrm{CaCl}{ }_{2}$. The obtained data indicate that the enzyme reaction does not take place without calcium ions, and the cations $\mathrm{Cs}^{+}$, $\mathrm{Mg}^{2+}, \mathrm{Sr}^{2+}, \mathrm{Cd}^{2+}, \mathrm{Fe}^{2+}, \mathrm{Co}^{2+}, \mathrm{Ni}^{2+}$ in the absence of

$A$

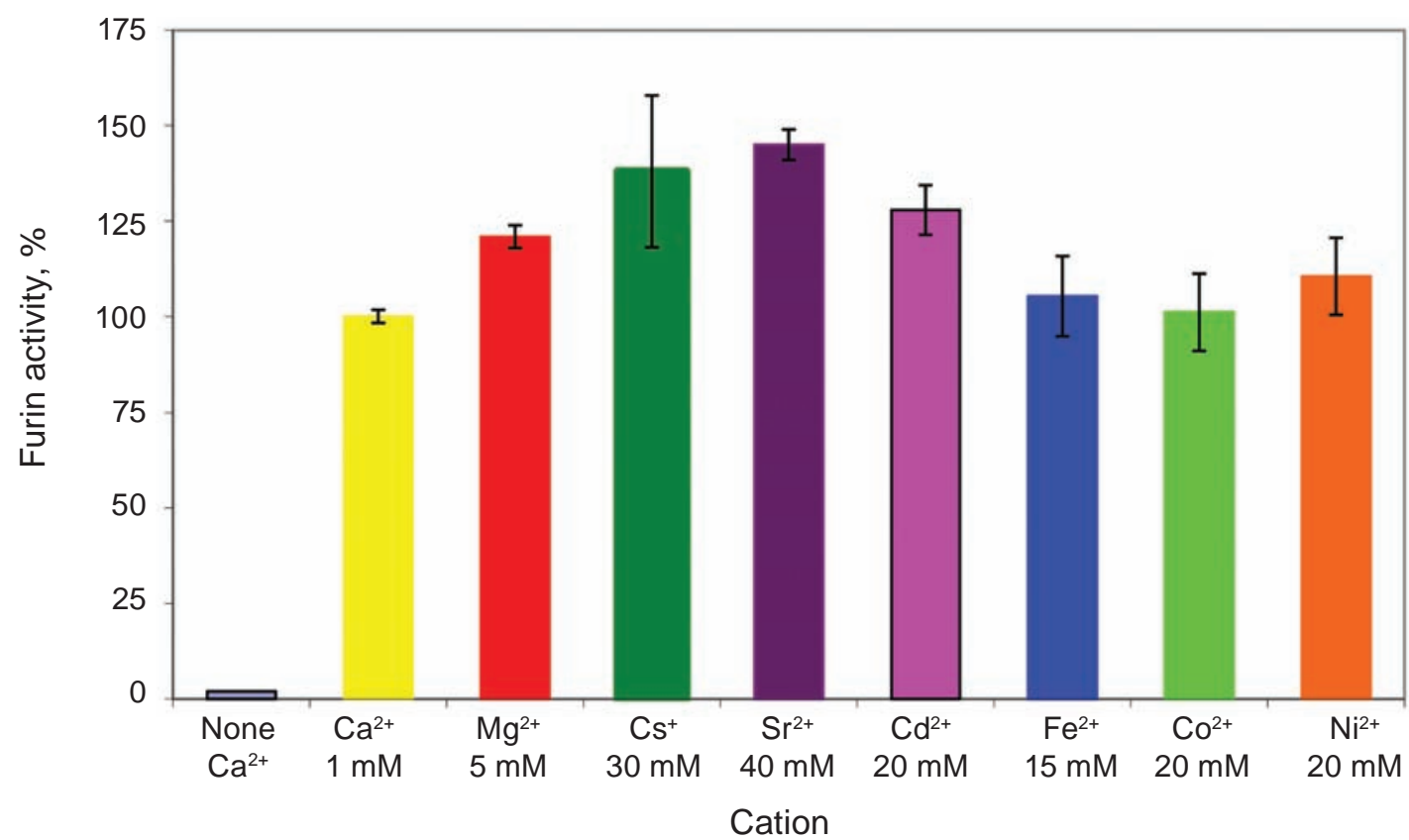

B

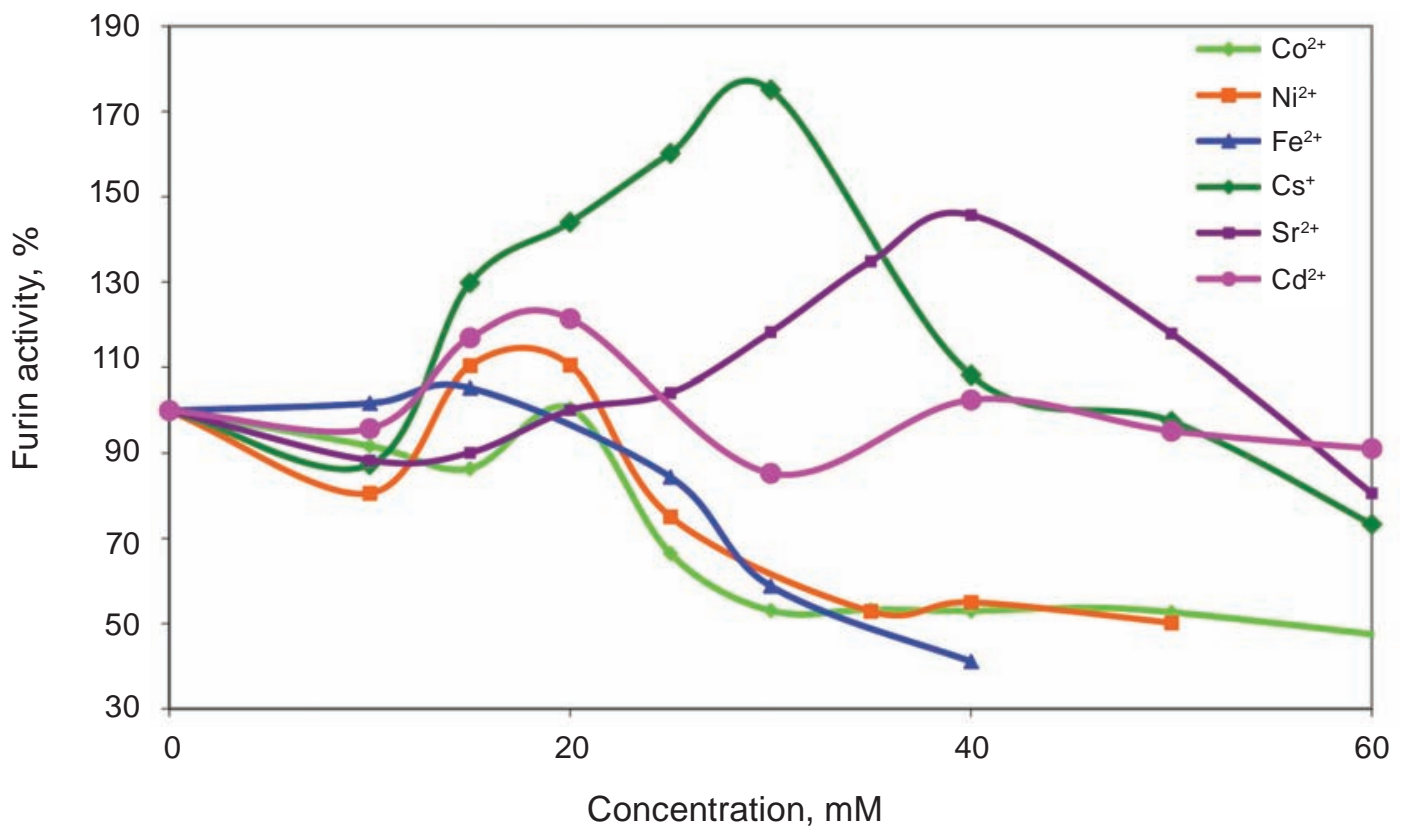

Fig. 1. Effects of cations on furin activity: A) the maximum value of enzyme activity; $B$ ) the dependence of furin activity on cation concentration 
calcium ions are not able to activate furin (the data are not presented).

When investigating the effect of different concentrations of ions on furin activity, it was found that the cations under study are capable of activating it at concentrations, depending on the ion nature. With gradual increasing of the cations concentration (from zero to $\sim 10-15 \mathrm{mM}$ ) in incubation media, a slight inactivation of the enzyme is observed with following activation. Further raising of ions concentration led to the increasing of furin activity. The position of maximal enzyme activity depends on the ion nature. Thus, for $\mathrm{Fe}^{2+}$, maximum activity of furin is achieved at a concentration of $15 \mathrm{mM}$, and for $\mathrm{Cd}^{2+}$, $\mathrm{Co}^{2+}$ and $\mathrm{Ni}^{2+}$ it occures at $20 \mathrm{mM}$, while for $\mathrm{Cs}^{+}$, it is $30 \mathrm{mM}$, and $\mathrm{Sr}^{2+}$ maximizes the enzyme at $40 \mathrm{mM}$.

The ions $\mathrm{Fe}^{2+}, \mathrm{Co}^{2+}, \mathrm{Ni}^{2+}$ (concentration of 15$20 \mathrm{mM}$ ) were shown to have insignificant effect on the activity of furin: their effect is actually within the error of the experiments. In this connection, further investigations of these ions have not been carried out.

According to Rockwell N. C. and Fuller R. S. [15], the effects of metal ions on the enzyme are explained by the fact that the enzyme is able to interact with cations stepwise and this causes the formation of several forms of enzyme, differing in the number of ions associated with the protein globule: $\mathrm{E}^{0}$, $\mathrm{E}^{\mathrm{M}+}$ and $\mathrm{E}^{2 \mathrm{M}+}$. Stimulation of furin is explained by the ion interaction with the site of high affinity and by formation of the $\mathrm{E}^{\mathrm{M}+}$-form, while furin inhibition occurs due to the attachment of the ion to the center with low affinity and the appearance of the $\mathrm{E}^{2 \mathrm{M}+}$-form.

To estimate furin affinity for the ions under study, the Lineweaver-Burk graphs were plotted for the upstream section of the dependence of enzyme

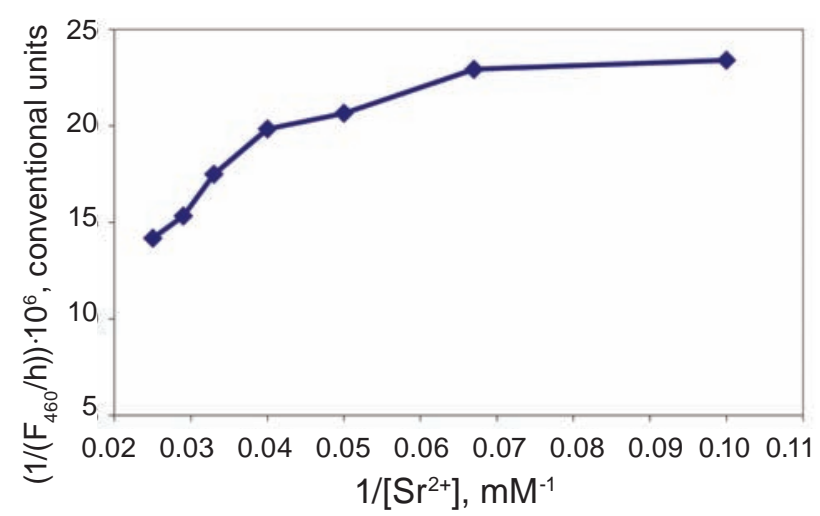

Fig. 2. The Lineweaver-Burk plot of the effect of strontium ions on furin activity

activity on the concentration of the corresponding salts. As an example, Fig. 2 shows the LineweaverBurk graph for strontium ions.

It can be seen that this graph is nonlinear. In the first approximation, it may be presented by two more or less linear sections: one of them for low concentrations, and the other one for higher concentrations of strontium. A graph plotted for low strontium concentrations $(10-25 \mathrm{mM})$ is a straight line. This allows us to estimate the apparent constant of furin activation by strontium ions, interacting with the center of high affinity $\left(K_{\mathrm{Sr}}=4.2 \mathrm{mM}\right)$.

Using Lineweaver-Burk plots for other ions, the apparent constants of furin activation by these ions were similarly evaluated. The results are presented in a Table. It shows the nature of the cations, their concentrations, at which maximum activity of furin takes place, the values of the apparent activation constants of the enzyme by these ions and the data of reducing of the ions affinity for furin in comparison with that of $\mathrm{Ca}^{2+}$. It is easy to notice that in comparison with $\mathrm{Ca}^{2+}$, the affinity of the studied ions for

Physicochemical characteristics of furin interaction with cations

\begin{tabular}{c|c|c|c|c}
\hline Cations & $\begin{array}{c}\text { Concentration } \\
\text { of cations, } \\
\mathrm{mM}\end{array}$ & Furin activity, \% & $\begin{array}{c}\text { * Constant of } \\
\text { furin activation } \\
\text { by cations, } \mathrm{mM}\end{array}$ & $\begin{array}{c}\text { The decrease in ion affinity } \\
\text { for furin compared to enzyme } \\
\text { affinity for } \mathrm{Ca}^{2+} \text {, multiplicity }\end{array}$ \\
\hline $\mathrm{Ca}^{2+}$ & 1 & $100 \pm 1.7$ & $0.235(0.200)$ & - \\
$\mathrm{Mg}^{2+}$ & 5 & $126.9 \pm 3.0$ & $(1.08)$ & $\sim 5$ times \\
$\mathrm{Cd}^{2+}$ & 20 & $127.0 \pm 6.5$ & 19.0 & 81 times \\
$\mathrm{Cs}^{+}$ & 30 & $150.4 \pm 29.1$ & 34.8 & 149 times \\
$\mathrm{Sr}^{2+}$ & 40 & $145.0 \pm 4.0$ & 4.2 & 18 times \\
\hline
\end{tabular}

*Note: The literature data are shown in parentheses for $\mathrm{Ca}^{2+}[1]$ and $\mathrm{Mg}^{2+}[16]$ 
the enzyme decreases sharply: for magnesium ions, it is reduced 5 times, for cadmium - 80 times, for cesium - almost 150 times, and for strontium - 18 .

To sum up, we have made a conclusion that the studied ions in model experiments showed the same behaviors, concerning furin activity: firstly they activated it, with the subsequent increasing in cation concentration the maximum activity of the enzyme is reached, followed by its decline. We speculate that $\mathrm{Cs}^{+}, \mathrm{Sr}^{2+}, \mathrm{Cd}^{2+}$ are not able to influence the activity of the enzyme under physiological conditions, as due to their low affinity for furin, they cannot replace $\mathrm{Ca}^{2+}$ from the calcium-binding center of the enzyme and cannot compete with calcium ions for furin. In other words, the effects of the studied cations on furin at physiological concentrations of $\mathrm{Ca}^{2+}$ and nontoxic concentrations of the cations have no biological consequences.

\section{ВПЛИВ КАТІОНІВ НА АКТИВНІСТЬ ФУРИНУ}

\section{T. В. Осадчук', О. В. Шибирин ${ }^{1}$, \\ А. В. Семироз' ${ }^{1}$ О. М. Бондаренко ${ }^{1}$, B. K. Kiбipє $\boldsymbol{B}^{1,2}$}

\author{
${ }^{1}$ Інститут біоорганічної хімії \\ та нафтохімії НАН України, Київ; \\ e-mail: osadchuk@bpci.kiev.ua; \\ ${ }^{1}$ Інститут біохімії ім О. В. Палладіна \\ НАН України, Київ
}

Фурин - найбільше вивчена пропротеїнконвертаза ссавців, здійснює процесинг неактивних попередників протеїнів, перетворюючи їх у біологічно активні поліпептиди. Ми дослідили вплив на активність фурину катіонів таких металів: цезію, стронцію, кадмію, заліза, кобальту та нікелю і показали, що в присутності $\mathrm{Ca}^{2+}(1 \mathrm{mM})$ ці іони здатні активувати фурин, причому положення піку активності залежить від природи іона. Зокрема, для $\mathrm{Fe}^{2+}$ воно спостерігалось за концентрації іона 15 мМ, тоді як для $\mathrm{Cd}^{2+}, \mathrm{Co}^{2+}$ та $\mathrm{Ni}^{2+}$ максимальна активність знаходилась при 20 мМ, для $\mathrm{Cs}^{+}$при 30 мМ і для $\mathrm{Sr}^{2+}-40$ мМ. Побудовою графіків у координатах Лайнуївера-Берка за низьких концентрацій катіонів висхідної гілки залежності активності фурину від концентрації іона, здійснена оцінка спорідненості катіонів до фурину. Знайдено, що їх афінність у порівнянні з $\mathrm{Ca}^{2+}$ різко зменшена ( у $18-150$ разів). Отже за фізіологічних умов катіони, що вивчалися, не здатні конкурувати з іонами кальцію за фурин і тому в природному середовищі не можуть впливати на його активність.

К л ю ч о в і с л о в а: фурин, вплив катіонів, активність фурину, активація, інгібування.

\section{ВЛИЯНИЕ КАТИОНОВ НА АКТИВНОСТЬ ФУРИНА}

T. В. Осадчук', Е. В. Шибирин ${ }^{1}$,

А. В. Семироз ${ }^{1}$ О. Н. Бондаренко ${ }^{1}$, B. К. Кибирев ${ }^{1,2}$

${ }^{1}$ Институт биоорганической химии и нефтехимии НАН Украины, Киев; e-mail: osadchuk@bpci.kiev.ua;

${ }^{2}$ Институт биохимии им. А. В. Палладина НАН Украины, Киев

Фурин - наиболее изученная пропротеинконвертаза млекопитающих, осуществляет процессинг неактивных протеиновых предшественников, превращая их в биологически активные полипептиды. Мы изучили влияние на активность фурина катионов следующих металлов: цезия, стронция, кадмия, железа, кобальта и никеля и показали, что в присутствии $\mathrm{Ca}^{2+}(1 \mathrm{MM})$ эти ионы способны активировать энзим, причем положение пика активности зависит от природы иона. В частности, для $\mathrm{Fe}^{2+}$ оно наблюдалось при концентрации катиона 15 мМ, тогда как для $\mathrm{Cd}^{2+}, \mathrm{Co}^{2+}$ и $\mathrm{Ni}^{2+}$ максимальная активность фурина находилась при $20 \mathrm{mM}$, для $\mathrm{Cs}^{+}$при $30 \mathrm{mM}$, и для ионов стронция - 40 мМ. Построением графиков в координатах Лайнуивера-Берка для низких концентраций ионов восходящей ветви зависимости активности фурина от концентрации катиона, осуществлена оценка сродства ионов к энзиму. Найдено, что их аффинность по сравнению с $\mathrm{Ca}^{2+}$ резко снижена ( в 18-150 раз). Следовательно, при физиологических условиях исследуемые катионы не способны конкурировать с ионами кальция за фурин, и в природной среде не могут влиять на его активность.

К л ю че вы е с л о в а: фурин, влияние катионов, активность фурина, активация, ингибирование. 


\section{References}

1. Molloy SS, Bresnahan PA, Leppla SH, Klimpel KR, Thomas G. Human furin is a calcium-dependent serine endoprotease that recognizes the sequence Arg-X-X-Arg and efficiently cleaves anthrax toxin protective antigen. J Biol Chem. 1992; 267(23): 1639616402.

2. Hosaka M, Nagahama M, Kim WS, Watanabe T, Hatsuzawa K, Ikemizu J, Murakami K, Nakayama K. Arg-X-Lys/Arg-Arg motif as a signal for precursor cleavage catalyzed by furin within the constitutive secretory pathway. J Biol Chem. 1991; 266(19): 12127-12130.

3. Thomas G. Furin at the cutting edge: from protein traffic to embryogenesis and disease. Nat Rev Mol Cell Biol. 2002; 3(10): 753-766.

4. Artenstein AW, Opal SM. Proprotein convertases in health and disease. $N$ Engl J Med. 2011; 365(26): 2507-2518.

5. Basak A. Inhibitors of proprotein convertases. J Mol Med (Berl). 2005; 83(11): 844-855.

6. De UC, Mishra P, Pal PR, Dinda B, Basak A. Non-peptide inhibitors of proprotein convertase subtilisin kexins (PCSKs): An overall review of existing and new data. Colloquium Series Protein Activ Cancer. 2012; 1(3): 1-76.

7. Kibirev VK, Osadchuk TV. Structure and properties of proprotein convertase inhibitors. Ukr Biokhim Zhurn. 2012; 84(2): 5-29. (In Russian).

8. Ramos-Molina B, Lick AN, Blanco EH, PosadaSalgado JA, Martinez-Mayorga K, Johnson AT, Jiao GS, Lindberg I. Identification of potent and compartment-selective small molecule furin inhibitors using cell-based assays. Biochem Pharmacol. 2015; 96(2): 107-118.

9. Sielaff F, Than ME, Bevec D, Lindberg I, Steinmetzer T. New furin inhibitors based on weakly basic amidinohydrazones. Bioorg Med Chem Lett. 2011; 21(2): 836-840.

10. Kibirev VK, Osadchuk TV, Kozachenko OP, Kholodovych V, Fedoryak D, Brovarets VS.
Synthesis, biological evaluation and docking of novel bisamidinohydrazones as non-peptide inhibitors of furin. Ukr Biochem J. 2015; 87(1): 55-63.

11. Becker GL, Hardes K, Steinmetzer T. New substrate analogue furin inhibitors derived from 4-amidinobenzylamide. Bioorg Med Chem Lett. 2011; 21(16): 4695-4697.

12. Dahms SO, Hardes K, Becker GL, Steinmetzer T, Brandstetter H, Than ME. X-ray structures of human furin in complex with competitive inhibitors. ACS Chem Biol. 2014; 9(5): 1113-1118.

13. Casey JR, Grinstein S, Orlowski J. Sensors and regulators of intracellular pH. Nat Rev Mol Cell Biol. 2010; 11(1): 50-61.

14. Izidoro MA, Gouvea IE, Santos JA, Assis DM, Oliveira V, Judice WA, Juliano MA, Lindberg I, Juliano L. A study of human furin specificity using synthetic peptides derived from natural substrates, and effects of potassium ions. Arch Biochem Biophys. 2009; 487(2): 105-114.

15. Rockwell NC, Fuller RS. Specific modulation of Kex2/furin family proteases by potassium. $J$ Biol Chem. 2002; 277(20): 17531-17537.

16. Izidoro MA, Assis DM, Oliveira V, Santos JA, Juliano MA, Lindberg I, Juliano L. Effects of magnesium ions on recombinant human furin: selective activation of hydrolytic activity upon substrates derived from virus envelope glycoprotein. Biol Chem. 2010; 391(9): 11051112.

17. Podsiadlo P, Komiyama T, Fuller RS, Blum O. Furin inhibition by compounds of copper and zinc. J Biol Chem. 2004; 279(35): 36219-36227.

18. Abosede OA. Review on heavy metals contamination in the environment. Eur J Earth Environ. 2017; 4(1): 1-6.

19. Oves M, Saghir Khan M, Huda Qari A, Nadeen Felemban M, Almeelbi T. Heavy metals: biological importance and detoxification strategies. J Bioremed Biodeg. 2016; 7(2): 334350. 